\title{
Alternative therapeutic strategies to fight bacterial infections
}

\author{
Leila Mousavifar ${ }^{1,2 *}$ and René Roy ${ }^{1,2,3}$ \\ ${ }^{1}$ LDepartment of Chemistry, University of Quebec in Montreal, PO Box 8888, Succ.Centre-Ville, Montreal, Quebec H3C 3P8, Canada \\ ${ }^{2}$ INRS-Institut Armand-Frappier, University of Quebec, 531 boul. Prairie, Laval, Quebec, H7V 1B7, Canada \\ ${ }^{3}$ Glycovax Pharma Inc., 424 Guy, Suite 202, Montreal, Quebec, H3J 1S6, Canada
}

\section{Introduction}

In spite of the large arsenal of antibiotherapies that have help humanities fighting bacterial infections, we are still facing diseases, hospitalization, and death caused by pathogenic agents [1-8]. The advent of the first sulfa drugs in the mid-thirties has launched almost a century of race toward the discoveries of new therapeutic agents by the pharmaceutical industries. The development of the Gram +ve linezolid in 2000 as the first family members of oxazolidinones as well as the Gram-negative lipopeptide antibiotic daptomycin, first discovered by Eli Lilly in 1980 but commercialized in the US in 2003 (23 years gap) have successfully lifted the long innovation gap in the medicinal chemistry era (Figure 1). Ceftaroline, a member of the fifth-generation cephalosporins discovered in 2010 is known to be particularly active against methicillin resistant Staphylococcus aureus (SARM), thus marking the beginning of alternative weapons against this particularly resilient infectious agent.

The advent of medicinal chemistry has allowed the relatively fast discoveries of diverse families of antibiotics working under a wide range of bactericidal or bacteriostatic mechanisms. Unfortunately, bacteria have similarly developed a plethora of defense mechanisms that include: (a) active efflux and sequestration of antibiotics by protein binding; (b) deactivation by enzymatic modification; (c) modification of antibiotic receptors; (d) metabolic bypass of the inhibited reaction; (e) overproduction of the antibiotic targets $[9,10]$.

Since the discoveries of a plethora of therapeutics antibacterial agents, working on more or less similar mechanisms, scientists developed several additional strategies encompassing alternative mechanisms (Table 1). They ranged from cell wall destructions through polycationic entities such as polypeptides and nanoparticles [11,12]; bacterial starving by blocking nutrients input [13]; blocking genes and proteins expressions through siRNA [14]; triggering immune responses by vaccines directed against cell wall components such as capsular polysaccharides, etc. $[15,16]$. This last approach has been particularly successful in eradicating bacterial infections caused by Streptococcus pneumoniae, Neisseria meningitidis, Haemophilus influenza type $b$ and so on [17-19].

Of particular interest was the discovery that numerous bacteria express carbohydrate-binding proteins called lectins as virulence factors [31]. In these cases, the bacterial infection is initiated by a carbohydrate-protein recognition process (adhesion) from which the lectins bind to glycoconjugate receptors (glycoproteins, glycolipids) on the host cells (Figure 2). The ensuing steps include the release of deadly
Table 1. List of alternative therapies against bacterial infections and their mechanism of action

\begin{tabular}{|c|c|c|c|}
\hline Strategy & Therapeutic agent & Action mechanism & References \\
\hline 1 & Nanoparticles & $\begin{array}{l}\text { Blocking biofilm } \\
\text { formation }\end{array}$ & 12 \\
\hline 2 & Quoring sensing & $\begin{array}{c}\text { Blocking bacterial } \\
\text { communication and } \\
\text { biofilms }\end{array}$ & 20 \\
\hline 3 & Siderophore & Enzyme co-factors & 21 \\
\hline 4 & Polycationic peptides & Membrane disruption & 11 \\
\hline 5 & Polycationic NPs & Membrane disruption & 20 \\
\hline 6 & Phytochemicals & Varied & 22 \\
\hline 7 & $\begin{array}{c}\text { Repurposing anticancer } \\
\text { drugs }\end{array}$ & Varied & 23 \\
\hline 8 & Vaccines & $\begin{array}{l}\text { Antibody-directed } \\
\text { bacterial antigens }\end{array}$ & $15-19$ \\
\hline 9 & $\begin{array}{c}\text { Antisense } \\
\text { oligonucleotides }\end{array}$ & $\begin{array}{l}\text { Inhibition of gene } \\
\text { expression }\end{array}$ & 14 \\
\hline 10 & $\begin{array}{l}\text { Peptide Nucleic Acids } \\
\text { (PNA) }\end{array}$ & $\begin{array}{l}\text { Inhibition of gene } \\
\text { expression }\end{array}$ & 24 \\
\hline 11 & $\begin{array}{l}\text { Transition metals (ex. } \\
\text { Silver cations) }\end{array}$ & $\begin{array}{l}\text { Inner membrane } \\
\text { disruption }\end{array}$ & 13,25 \\
\hline 12 & Innate immunity & $\begin{array}{c}\text { Macrophage stimulation } \\
\text { through TLRs }\end{array}$ & 26 \\
\hline 13 & Adaptive immunity & $\begin{array}{l}\text { Antibody-antibiotic } \\
\text { conjugates }\end{array}$ & 27 \\
\hline 14 & Phage display & $\begin{array}{l}\text { Bacterial membrane } \\
\text { lysis }\end{array}$ & 28 \\
\hline 15 & Carbohydrate analogs & $\begin{array}{c}\text { Inhibition of } \\
\text { carbohydrate processing } \\
\text { enzymes }\end{array}$ & 29 \\
\hline 16 & Carbohydrates & Inhibition of adhesion & 30 \\
\hline 17 & Pilicides & $\begin{array}{l}\text { Inhibition of pili } \\
\text { formation }\end{array}$ & 38 \\
\hline
\end{tabular}

toxins and biofilm formation. Amongst these, Pseudomonas aeruginosa, uropathogenic E. coli, several Shigella species, and Burkholderia cenocepacia are representative examples. The case of uropathogenic E. coli infections (UPECs) is particularly well documented because the lectins responsible for the host cell adhesion are known and their structures fully characterized by X-ray crystallography [32]. The E.

*Correspondence to: Leila Mousavifar, Department of Chemistry, University of Quebec in Montreal, PO Box 8888, Succ.Centre-Ville, Montreal, Quebec H3C 3P8, Canada, E-mail: leilyanmousavifar@gmail.com

Received: September 13, 2018; Accepted: October 12, 2018; Published: October 17,2018 


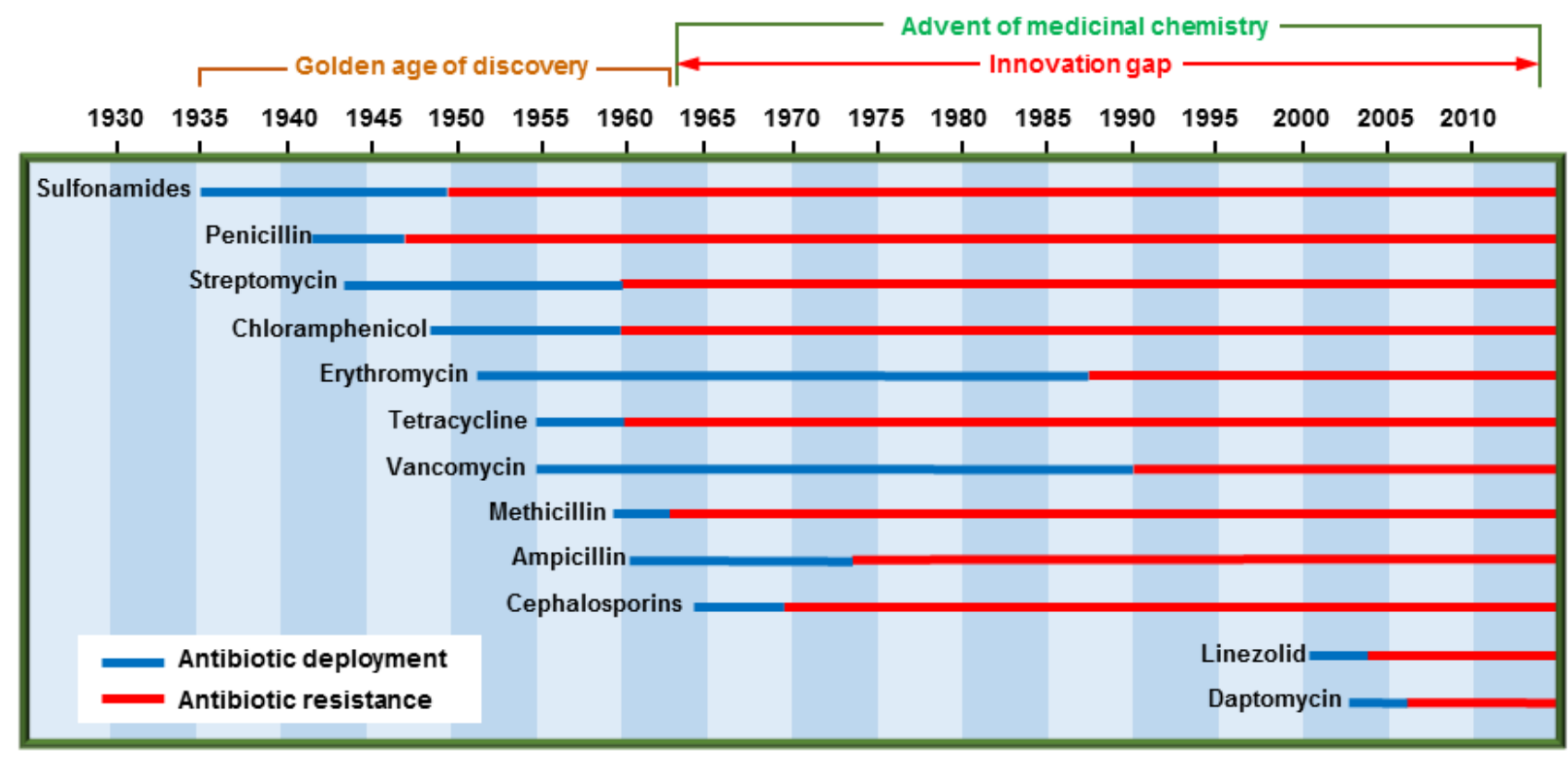

Figure 1. Development and bacterial resistance pattern of current antibiotics [9]

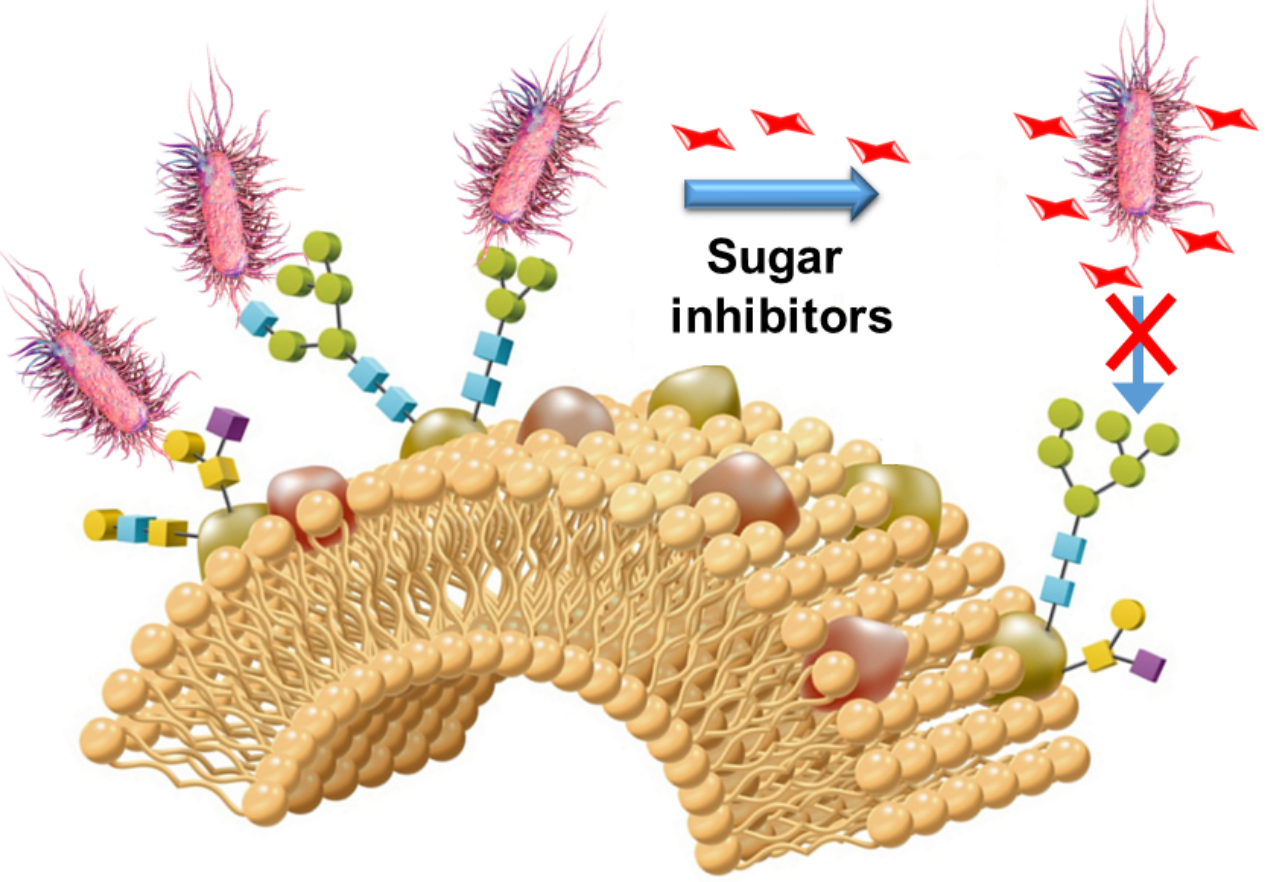

Figure 2. Blocking bacterial adhesion by carbohydrate anti-adhesives [33a]

coli FimH lectin has led to intensive medicinal chemistry efforts that ultimately allowed the discovery of small molecule inhibitors that recently successfully passed clinical Phase $1[33,34]$.

Actually, the proof of principle that clearly demonstrated the first examples of inhibition of bacterial adhesion by carbohydrates was obtained through the pioneering activities of Sharon et al. [35]. For instance, recent investigations showed the direct consequences of exposing carbohydrate ligands such as carbohydrate additives and $\alpha-\mathrm{D}$ mannopyranoside antagonists between uropathogenic E. coli CFT073 bound to human 5637 bladder epithelial cells in vitro (Figure 3) [36-38]. The binding of green fluorescent protein-labelled E. coli strain (CFT073GFP) could be efficiently inhibited in the presence of low concentration of the sugar as shown by fluorescence microscopy. In addition, there are growing demonstrations that the effect of mannopyranoside antagonists can alter the binding of various uropathogenic E. coli strains in microarray settings including human tissues. Hence, the therapeutic value of identifying potent sugar antagonists against adherent invasive E. coli strains represents an important goal in our arsenal of new drug development. 

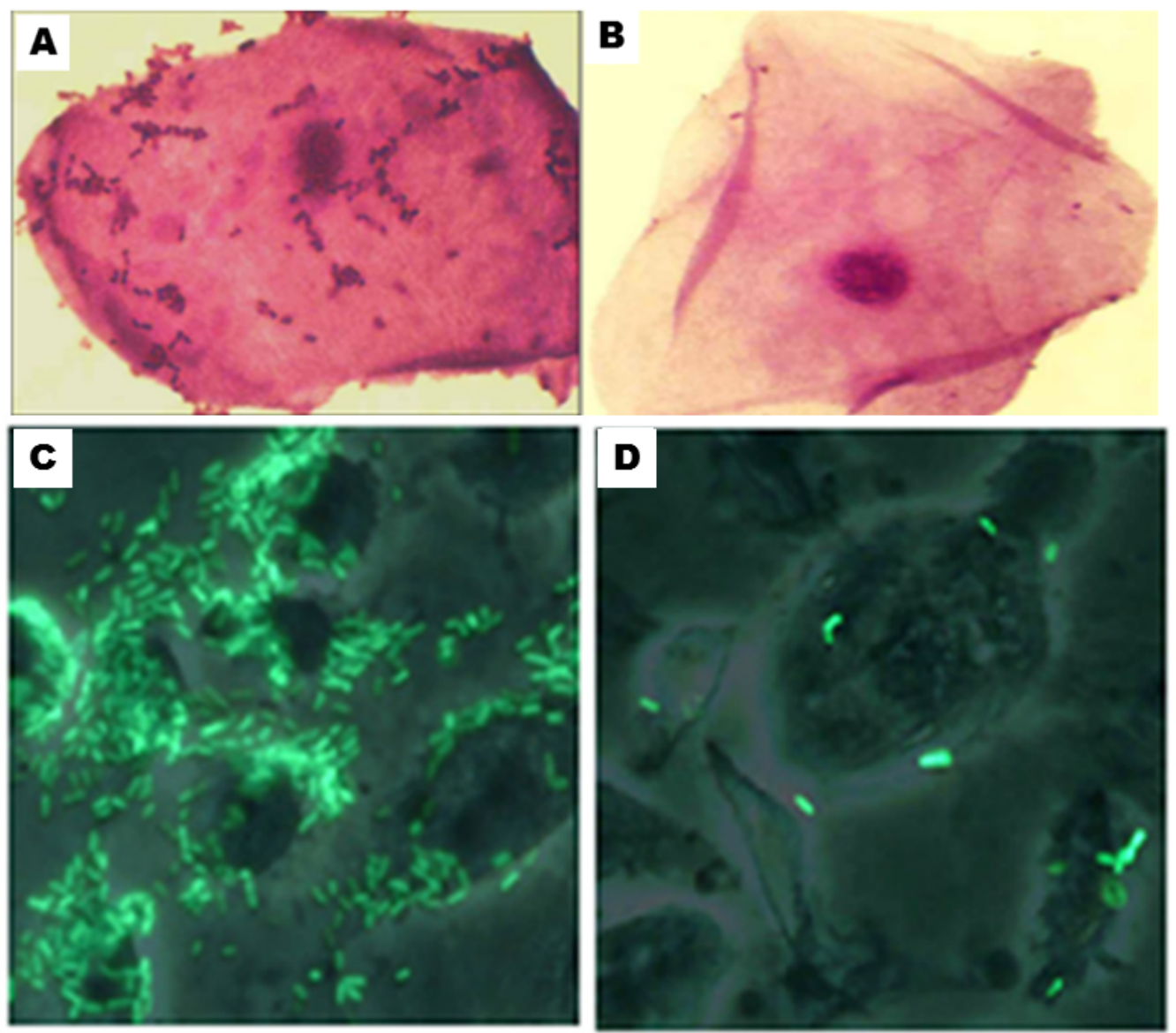

Figure 3. (Top panel): Adherence of E. coli to epithelial cells in the presence of sucrose (A) and mannose (B); adapted [36] (Bottom panel): Effect of type 1 fimbriae on adherence of uropathogenic $E$. coli to human bladder epithelial cells in vitro $(\mathbf{C})$ and inhibition of binding in the presence of methyl $\alpha$-D-mannopyranoside using fluorescence microscopy (D) adapted [37]

\section{References}

1. Munita JM, Bayer AS, Arias CA (2015) Evolving resistance among Gram-positive pathogens. Clin Infect Dis 61 Suppl 2: S48-57. [Crossref]

2. Drews J (1998) Innovation deficit revisited: reflections on the productivity of pharmaceutical R\&D. Drug Discovery Todays 3: 491-494.

3. Crouch E, Dickes L, Kahle A (2015) Review on Antibiotic Resistance Adv. Pharmacoepidemiol. Drug Saf 4: 183.

4. Simpkin VL, Renwick MJ, Kelly R, Mossialos E (2017) Incentivising innovation in antibiotic drug discovery and development: progress, challenges and next steps. $J$ Antibiot (Tokyo) 70: 1087-1096. [Crossref]

5. Meylan S, Andrews IW, Collins JJ (2018) Targeting Antibiotic Tolerance, Pathogen by Pathogen. Cell 172: 1228-1238. [Crossref]

6. Yelin I, Kishony R (2018) Antibiotic Resistance. Cell 172: 1136-1136. [Crossref]

7. Simões NG, Bettencourt AF, Monge N, Ribeiro IAC (2017) Novel Antibacterial Agents: An Emergent Need to Win the Battle Against Infections. Mini Rev Med Chem 17: 1364-1376. [Crossref]

8. Kaczor AA, Polski A, Sobotka-Polska K, Pachuta-Stec A, Makarska-Bialokoz M, et al. (2017) Novel Antibacterial Compounds and Their Drug Targets - Successes and Challenges. Curr Med Chem 24, 1-19.

9. http://emerald.tufts.edu/med/apua/about_issue/antibiotic_res.shtml.

10. Ritter TK, Wong CH (2001) Carbohydrate-Based Antibiotics: A New Approach to Tackling the Problem of Resistance. Angew Chem Int Ed Engl 40: 3508-3533. [Crossref]

11. Falanga A, Lombardi L, Franci G, Vitiello M, Iovene MR (2016) Marine Antimicrobial Peptides: Nature Provides Templates for the Design of Novel Compounds against Pathogenic Bacteria. Int J Mol Sci 17: 1-18.
12. (a) Mi G, Shi D, Wang M, Webster TJ (2018) Reducing Bacterial Infections and Biofilm Formation Using Nanoparticles and Nanostructured Antibacterial Surfaces. $A d v$ Healthc Mater 7: 1-23; (b) Rimondino GN, Oksdath-Mansilla G, Brunetti V, Strumia MC (2017) More than Just Size: Challenges and Opportunities of Hybrid Dendritic Nanocarriers. Curr Pharm Des 23: 3142-3153; (c) AlMatar M, Makky EA, Var I, Koksal F (2018) The Role of Nanoparticles in the Inhibition of Multidrug Resistant Bacteria and Biofilms. Curr Drug Deliv 15: 470-484; (d) Ergene C, Yasuhara K, Palermo EF (2018) Biomimetic Antimicrobial Polymers: Recent Advances in Molecular Design. Polym Chem 9: 2407-2427; (e) Mocan T, Matea CT, Pop T, Mosteanu O, Buzoianu $\mathrm{AD}$, et al. (2017) Carbon Nanotubes as Anti-Bacterial Agents. Cell Mol Life Sci 74 3467-3479; (f) Lin LCW, Chattopadhyay S, Lin JC, Hu CMJ (2018) Advances and Opportunities in Nanoparticle- and Nanomaterial-Based Vaccines against Bacteria Infections. Adv Healthcare Mater 7: 1-26.

13. Palmer LD, Skaar EP (2016) Transition Metals and Virulence in Bacteria. Annu Rev Genet 50: 67-91. [Crossref]

14. (a) Xue XY, Mao XG, Zhou Y, Chen Z, Hu Y, et al. (2018) Advances in the Delivery of Antisense Oligonucleotides for Combating Bacterial Infectious Diseases. Nanomedicine Nanotechnology, Biol Med 14: 745-758; (b) Hegarty JP, Stewart DB (2018) Advances in Therapeutic Bacterial Antisense Biotechnology. Appl Microbiol Biotechnol 102: 1055-1065.

15. Roy R (2004) New trends in carbohydrate-based vaccines. Drug Discov Today Technol 1: 327-336. [Crossref]

16. Adamo R (2017) Advancing Homogeneous Antimicrobial Glycoconjugate Vaccines Acc Chem Res 50: 1270-1279.

17. Costantino P, Rappuoli R, Berti F (2011) The design of semisynthetic and synthetic glycoconjugate vaccines. Expert Opin. Drug Discovery 6: 1045-1067.

18. Jennings HJ, Roy R, Gamian A (1986) Induction of meningococcal group B polysaccharide-specific IgG antibodies in mice by using an N-propionylated B polysaccharide-tetanus toxoid conjugate vaccine. J Immunol 137: 1708-1713. [Crossref] 
19. Verez-Bencomo V, Fernandez-Santana V, Hardy E, Toledo ME, Rodrguez MC, et al. (2004) A synthetic conjugate polysaccharide vaccine against Haemophilus influenzae Type b. Science 305: 522-525.

20. (a) Muimhneachain FO, Reen FJ, O'Gara F, McGlacken GP (2018) Analogues of Pseudomonas Aeruginosa Signalling Molecules to Tackle Infections. Org Biomol Chem 16: 169-179; (b) Wolfmeier H, Pletzer D, Mansour SC, Hancock REW (2018) New Perspectives in Biofilm Eradication. ACS Infect Dis 4: 93-106.

21. Ghosh M, Lin YM, Miller PA, Mollmann U, Boggess WC, et al. (2018) Siderophore Conjugates of Daptomycin are Potent Inhibitors of Carbapenem Resistant Strains of Acinetobacter baumannii. ACS Infect Diseases Ahead of Print.

22. Borges A, Abreu AC, Dias C, Saavedra MJ, Borges F, et al. (2016) New Perspectives on the Use of Phytochemicals as an Emergent Strategy to Control Bacterial Infections Including Biofilms. Molecules 21: 1-41.

23. Soo VWC, Kwan BW, Quezada H, Castillo-juarez I, Perez-eretza B (2017) Repurposing of Anticancer Drugs for the Treatment of Bacterial Infections Valerie. Curr Top Med Chem 17: 1157-1176.

24. (a) Ghosal A (2017) Is Antibacterial PNA the Answer for Combating Multidrug Resistant Bacterial Infections? Int J Biosci 10: 408-410; (b) Good L, Sandberg R, Larsson O, Nielsen PE, Wahlestedt C (2000) Antisense PNA Effects in Escherichia Coli Are Limited by the Outer-Membrane LPS Layer. Microbiology 146: 2665-2670.

25. Duran N, Duran M, Bispo de Jesus M, Seabra AB, Favaro WJ, et al. (2016) Silver nanoparticles: A new view on mechanistic aspects on antimicrobial activity. Nanomedicine 12: 789-799.

26. (a) Stocks CJ, Schembri MA, Sweet MJ, Kapetanovic R (2018) For When Bacterial Infections Persist: Toll-like Receptor-Inducible Direct Antimicrobial Pathways in Macrophages. J Leukoc Biol 103, 35-51; (b) Xu Qun, Zhu Gengzheng, Li Jing, Cheng K (2017) Development of Antibacterial Drugs by Targeting Toll-Like Receptors. Curr Top Med Chem 17, 270-277.

27. (a) Feigman MJS, Pires MM (2018) Synthetic Immunobiotics: A Future Success Story in Small Molecule-Based Immunotherapy? ACS Infect Dis 4: 664-672; (b) Mariathasan S, Tan MW (2017) Antibody-Antibiotic Conjugates: A Novel Therapeutic Platform against Bacterial Infections. Trends Mol Med 23: 135-149.

28. (a) Rastogi V, Verma NP, Mishra AK, Nath G, Gaur PK, et al. (2018) An Overview on Bacteriophages: A Natural Nanostructured Antibacterial Agent. Curr Drug Deliv 15: 3-20; (b) Cisek AA, Dabrowska I, Gregorczyk KP, Wyzewski Z (2017) Phage Therapy in Bacterial Infections Treatment: One Hundred Years After the Discovery of Bacteriophages. Curr Microbiol 74: 277-283.
29. (a) Harit VK, Ramesh NG (2016) Amino-Functionalized Iminocyclitols: Synthetic Glycomimetics of Medicinal Interest. RSC Adv 6: 109528-109607; (b) Jeong D, Joo SW, Shinde VV, Cho E, Jung S (2017) Carbohydrate-Based Host-Guest Complexation of Hydrophobic Antibiotics for the Enhancement of Antibacterial Activity. Molecules 22: $1-15$.

30. Imberty A, Chabre YM, Roy R (2008) Glycomimetics and glycodendrimers as high affinity microbial anti-adhesins. Chemistry 14: 7490-7499. [Crossref]

31. Cecioni S, Imberty A, Vidal S (2015) Glycomimetics versus Multivalen Glycoconjugates for the Design of High Affinity Lectin Ligands. Chem Rev 115: 525561.

32. (a) Wellens A, Lahmann M, Touaibia M, Vaucher J, Oscarson S, et al. (2012) The Tyrosine Gate as a Potential Entropic Lever in the Receptor-Binding Site of the Bacterial Adhesin FimH. Biochemistry 51: 4790-4799; (b) Roos G, Wellens A, Touaibia M, Yamakawa N, Geerlings P, et al. (2013) Validation of Reactivity Descriptors to Assess the Aromatic Stacking within the Tyrosine Gate of FimH. ACS Med Chem Lett 4: 1085 1090; Touaibia M, Roy R, Bouckaert J (2017) Sites for Dynamic Protein-Carbohydrate Interactions of O- and C-Linked Mannosides on the E. Coli FimH Adhesin. Molecules 22: $1-18$

33. (a) Mousavifar L, Touaibia M, Roy R (2018) Development of Mannopyranoside Therapeutics Against Adherent-invasive E. coli Infections. Acc Chem Res in press; (b) Touaibia M, Krammer EM, Shiao T, Yamakawa N, Wang Q, et al. (2017) Sites for Dynamic Protein-Carbohydrate Interactions of O- and C-Linked Mannosides on the $E$. Coli FimH Adhesin. Molecules 22: 1101.

34. http://microbiome-summit.com/wp-content/uploads/sites/176/2016/02/1100 Rodolphe-Clerval-YES.pdf

35. Aronson M, Medalia O, Schori L, Mirelman D, Sharon N, et al. (1979) Prevention of colonization of the urinary tract of mice with Escherichia coli by blocking of bacterial adherence with methyl alpha-D-mannopyranoside. J Infect Dis 139: 329-332. [Crossref]

36. Al-Ghazzewi FH, Tester RF. (2014) Inhibition of the adhesion of Escherichia coli to human epithelial cells by carbohydrates. Bioactive Carbohydrate. Diet Fibre 4: 1-5.

37. Crepin S, Houle S, Charbonneau M, Mourez M, Harel J, et al. (2012) Decreased Expression of Type 1 Fimbriae by a Pst Mutant of Uropathogenic Escherichia Coli Reduces Urinary Tract Infection. Infect Immun 80: 2802-2815.

38. Aberg V, Almqvist F (2007) Pilicides-small molecules targeting bacterial virulence. Org Biomol Chem 5: 1827-1834.

Copyright: (C2018 Mousavifar L. This is an open-access article distributed under the terms of the Creative Commons Attribution License, which permits unrestricted use, distribution, and reproduction in any medium, provided the original author and source are credited. 